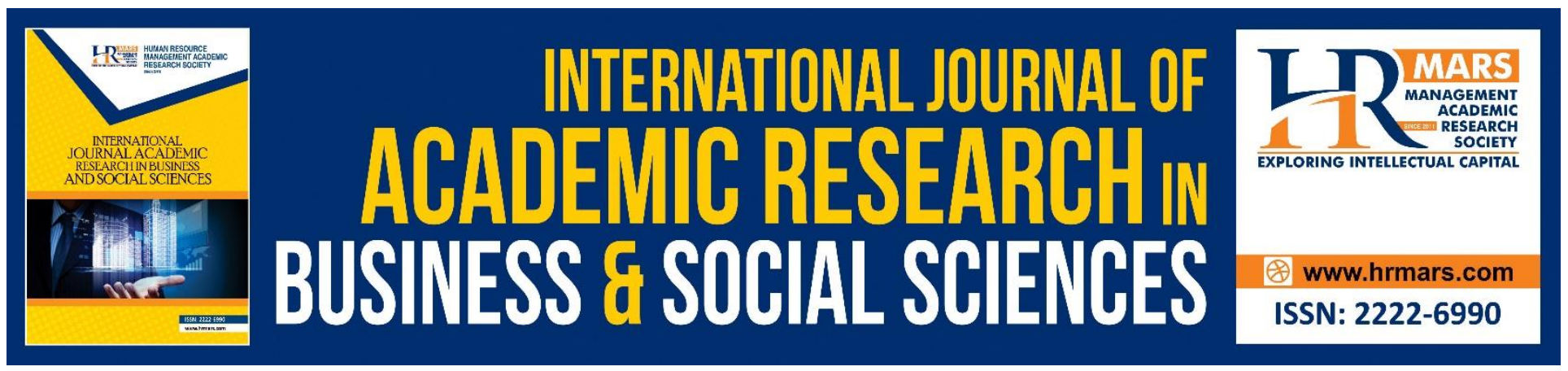

\title{
Agile Marketing Conceptual Framework for Private Higher Education Institutions
}

\author{
Yuslina Yusoff, Zuraini Alias, Mokhtar Abdullah, Zulkefli Mansor
}

To Link this Article: http://dx.doi.org/10.6007/IJARBSS/v9-i1/5896

DOI: $10.6007 /$ IJARBSS/v9-i1/5896

Received: 01 Dec 2018, Revised: 20 Dec 2019, Accepted: 11 Jan 2019

Published Online: 29 Jan 2019

In-Text Citation: (Yusoff, Alias, Abdullah, \& Mansor, 2019)

To Cite this Article: Yusoff, Y., Alias, Z., Abdullah, M., \& Mansor, Z. (2019). Agile Marketing Conceptual Framework for Private Higher Education Institutions. International Journal of Academic Research Business and Social Sciences, 9(1), 1418-1426.

Copyright: (C) 2019 The Author(s)

Published by Human Resource Management Academic Research Society (www.hrmars.com)

This article is published under the Creative Commons Attribution (CC BY 4.0) license. Anyone may reproduce, distribute, translate and create derivative works of this article (for both commercial and non-commercial purposes), subject to full attribution to the original publication and authors. The full terms of this license may be seen

at: http://creativecommons.org/licences/by/4.0/legalcode

\section{Vol. 9, No. 1, 2019, Pg. 1418 - 1426}

http://hrmars.com/index.php/pages/detail/IJARBSS

JOURNAL HOMEPAGE

Full Terms \& Conditions of access and use can be found at http://hrmars.com/index.php/pages/detail/publication-ethics 


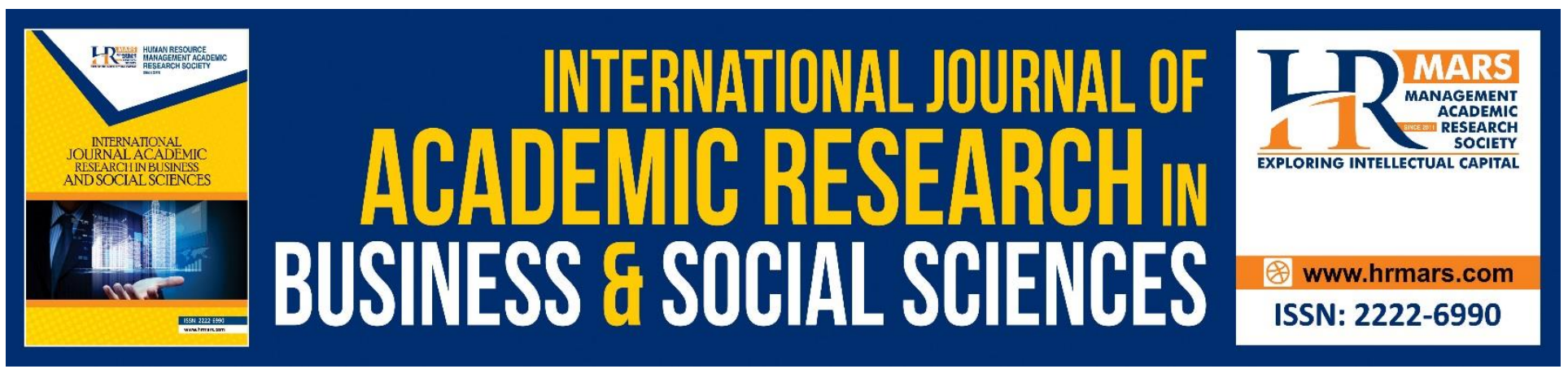

\title{
Agile Marketing Conceptual Framework for Private Higher Education Institutions
}

\author{
Yuslina Yusoff, Zuraini Alias \\ Faculty of Business and Accountancy, Universiti Selangor, Selangor. \\ Email:yuslina@unisel.edu.my,Email: zuraini@unisel.edu.my \\ Mokhtar Abdullah \\ Universiti Malaysia, Selangor. \\ Email: mokhtar.abdullah@unimy.edu.my \\ Zulkefli Mansor
}

Faculty of Information Science \& Technology, Universiti Kebangsaan Malaysia, Selangor.

Email: kefflee@ukm.edu.my

\begin{abstract}
Agile marketing is an iterative approach towards marketing strategy planning and implementation using frameworks like Scrum, Kanban and other Agile methodologies. This study aims to understand how agile can be adopted as a marketing strategy in higher education industry especially in Private Higher Education Institutions (PHEIs). This is because private higher education industry is fast becoming a very competitive business. Therefore, agile marketing is important in order to make sure PHEls use effective marketing strategy for sustainable customer relationships and sales over a longer period of time. In addition, with great competition in higher education industry, universities are challenged in their branding campaigns to recruit the best and brightest students, staff, and sustain their reputation. The literature shows that agile can be an effective tool in marketing strategies. However, research on the impact of agile marketing on brand equity is still in its infancy. Hence, this study will look into how agile marketing plays important roles in enhancing the brand equity in PHEls. This study reviews various literatures to propose a conceptual framework for agile marketing. Overall findings are expected to serve as a basis for universities to foster agile marketing in enhancing its brand and reputation.
\end{abstract}

Keywords: Brand equity, social media, customer based brand equity, brand, marketing, agile, agile interaction, marketing communication, PHEls. 
INTERNATIONAL JOURNAL OF ACADEMIC RESEARCH IN BUSINESS AND SOCIAL SCIENCES

Vol. 9, No. 1, Jan, 2019, E-ISSN: 2222-6990 @ 2019 HRMARS

\section{Overview of Agile}

The basic "agile" term derives from the Latin word agilis which means to drive, do, and see. The basic meaning of agile is to move quickly, lightly, and easily. In the 1930s, the automobile industry introduced the first agile concepts through the introduction of optimization concepts and work splitting (Von Rosing, Von Scheel, \& Gill, 2014). The term 'Agile Method' was then created in February 2001 by 17 leading developers.

Agile is a set of values and principles that provides a foundation for teams to make decisions, resulting in better outcomes. The actual definition of agile is found in the Agile Manifesto. The Manifesto makes it clear that agile is not a methodology. It is not a specific way of doing software development. It is not a framework or a process. In fact, most of the things that are marketed as agile tend to miss the point of what agile actually is.

The most important principle in agile is to take continuous feedback, learn from the previous duplications and try to improve in the next iteration. There is no concept of best practices. Better and better practices will keep on evolving as practitioners master their environment. Agile means taking risk. In the process, one may make mistakes but the important thing is to detect the mistakes early and fix them as soon as possible (Kamat, 2012).

Nowadays, agile is pushing into non-development parts of an organization. The rapid and volatile changes in information technology triggered many organizations to use agile methods, which are applied in business, sales, and marketing teams (Bruce, Daly and Towers, 2004; DeFauw, 2012). In today's marketplace, a marketer needs the skills, competency, instincts, and processes to be nimble-agile (Rascals, 2011). "Responsiveness" is the central idea of agility in the context of marketing (Christopher, Lowson, \& Peck, 2004). Traditional marketing is more motionless and lengthier with long lead-times, while agile marketing is shorter and more likely to be informationbased. The concept of agility has been widely accepted in the past years that there is no similar definition for it. Some definitions that have been laid out for agility supports one another. These definitions show the idea of speed and change in the business environment. Therefore, the following definitions can be presented for agility:

1. Agility that is flexibility, it is a state of dynamic, adapted to the specific circumstances, catering to the change and self-improvement (Hu Yuan and Zhang, 2009).

2. Agility is a response to the challenges posed by a business environment dominated by change and uncertainty (Zain, Rose, Abdullah and Masrom, 2004).

3. Agility is a reaction to the difficulties postured by a business domain overwhelmed by change and vulnerability (Prange, 2016).

4. Agile provides more customer's participation involvement, earlier testing, quick delivery and active requirements (Mansor, Yahya, Habibah, and Arshad, 2012). 
INTERNATIONAL JOURNAL OF ACADEMIC RESEARCH IN BUSINESS AND SOCIAL SCIENCES

Vol. 9, No. 1, Jan, 2019, E-ISSN: 2222-6990 @ 2019 HRMARS

\section{Agile Values}

According to Rosing et al. (2014), the six Agile Manifestos provide such essential statements that define agile as follows:

1. Individual and interactions over processes and tools

2. Working software over comprehensive documentation

3. Customer collaboration over contract negotiation

4. Responding to change over following a plan

5. Keeping the process agile

6. Keeping the process cost-effective

A number of researchers have also conveyed the agile values (Qumer and Henderson-Sellers, 2008). In addition to the values of the Manifesto, there are 12 principles that support the values. The principles are very general and less about telling what to do than they are about giving the ability to make good decisions in a particular situation.

Agile Principles

According to Hunt (2006), the Agile Principles do not insist on a method, but are rather described as a set of guiding statements which "Agile" should adapt to. Thus, agile methodologies should fit in to these principles:

1. Highest priority is to satisfy the customer.

2. Welcome change.

3. Deliver working software frequently.

4. Business people and developers must work together daily.

5. Build projects around motivated individuals.

6. Face-to-face communication is best.

7. Working software is the primary measure of progress.

8. Promote sustainable development.

9. Continuous attention to technical excellence and good design enhances agility.

10. Simplicity-the art of maximising the amount of work not done-is essential.

11. The best architectures, requirements and design emerge form self-organising teams.

12. Introspection - teams should regularly review itself and its processes to try and improve.

\section{Agility in Marketing}

Many ways exist in which agile concepts can be practised across various disciplines such as agile software development, agile project management, agile supply chain, agile manufacturing, agile service management, agile enterprise, and the list goes on (Mills, Sherrell, Boydstun and Guoqing Wei, 2006). Similarly, agile concepts can also be applied to marketing. With the improved technology advancement in communication and growth of digital marketing and social media marketing, agile is currently one of the most adopted methodologies (Yam, Lo and Tang, 2001).

In the last 30 to 40 years, the interactions to connect with customers were limited and static (Kim, Ko, Xu and Han, 2012). Nowadays, pushing information and customer experience have really changed and become more interactive and engaging. The interaction is a more intimate and organic level (Rader et al., 2014). This is because we have entered the "Age of Customer"; the emergence of customer advocacy as the dominant marketing strategy (Wilkie and Moore, 2003). The 
changes are revolutionizing the practice of marketing. The key source of competitive differentiation now is the customer centricity \{Formatting Citation\}. It is a new-fangled phenomenon. Literature confirms that companies investing in this strategy outperform the market (Sashi, 2012; Senn, Thoma, \& Yip, 2013). Digital marketing and digital customer experience is going to be the key area for competitive advantage.

Customer power shift becomes very important because it is a real opportunity to focus on customer-first attitude, and a customer-centric attitude (Hutter et al., 2013; Laroche, Habibi and Richard, 2013). It is no longer just a business first anymore, but customer first strategy. In addition, it is no more web and mobile, but it is a digital across channel with new engaging and cutting edge technology (Royle and Laing, 2014). The augmented reality technology which is applied in promotional activities nowadays is a prime example. The total power of all buyers is what makes up market power, and market power can sway the market.

Furthermore, marketing is all about simplicity and getting to the heart of why someone needs a product or service. Marketing is really about making things simple. It is the simplicity of the marketing message that drives consumerism (Pan, Vorvoreanu and Zhou, 2014; Urban, 2005). Thus, when a marketing message is simple, easy to understand, and evident, it works really well. Practical enrichment is the basis idea of agile marketing (Rascals, 2011). Figure 1 shows the different meaning of terms in agile and marketing. It demonstrate that the four agile values is analogous to marketing values where individual and interaction is resemble the customer centric, working software Is the customer profile, customer collaboration is the customer engagement and responding to change is the customer consent.

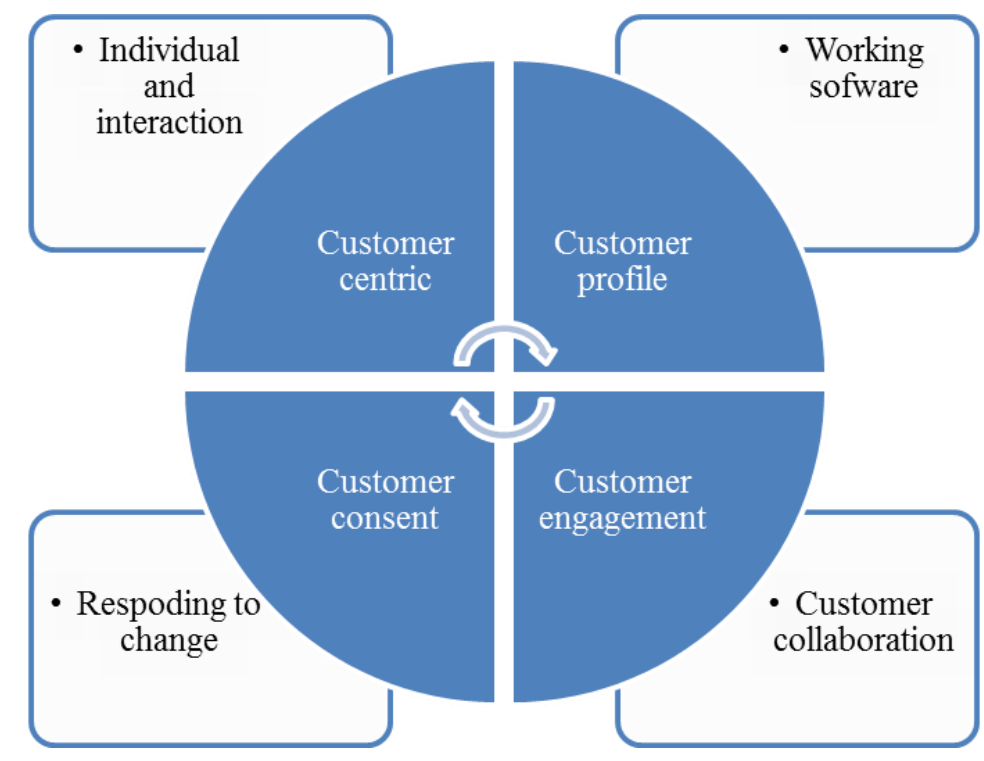

Figure 1: Aptness of Agile and Marketing Values (Author, 2018) 


\section{Adopting Agility in Marketing}

Recent developments in technology have heightened the need for agility. The issue of agility has received considerable critical attention across industry and academia. The history of agile concepts can be drawn back from 1930s (Rosing, Scheel and Gill, 2014). The nature of agile is flexibility and adoption. It puts people first, trusting that, working together; they can find or build solutions in an incremental way, expelling unnecessary requirements for value delivery (Rascals, 2011).

Operationalize Agile in Marketing

Agile methodology starting point was developed to prosper with customer developer relationships in software development (Hanssen and Fægri, 2006). Agile methodologies ability to improve time-to-market increases customer satisfaction (Baird and Riggins, 2012). To meet the demands of globalization, companies need to continually and rapidly access, absorb, and integrate ideas for innovation from around the world (Wilson and Doz, 2014). Additionally, marketers must become more agile to keep up with the speed of communication. In creating an agile marketing framework and to be successful with the content, the marketer must also be agile in understanding their audience (Johansen, 2012). Henceforth, this will affect awareness, engagement, lead generation and sales.

This follows (DeFauw, 2012) claims that agile marketing is to move at the speed of customer, real time marketing, digital experience delivery, personalization solution, information acceleration, integrated systems and strategies to leverage technology to deliver customer value in a digital ecosystem. With these factors in mind, the need for agility and responsiveness has been identified. However, more recent arguments summarised by Hellberg (2012) in her thesis, foundational elements of marketing solutions - like brand goals and audience understanding - will remain, the mediums, channels, contributors and pace must be constantly adjusted and optimized to reach audiences with valuable content.

Poolton et al. (2006) in their study have explored the agile methodologies and suggested a different approach, emphasizing close and continuous cooperation with the customers. Agile marketing presents an alternative to traditional marketing. Moreover, Conboy and Fitzgerald (2004) confirmed that agility is a quick adaptation to changes, which is very important in the highly dynamic and competitive market.

The most important about "marketing agility" is that the approach encourages companies to develop their marketing so that it can be reconfigured at a moment's notice. When opportunities arise, the company is well positioned to make customers aware of the immediate changed of offerings (Poolton et al., 2006). It is almost certain that agile marketing helps hit the targets, balances the need for speed with the pursuit for quality and lastly help to treat message content as a strategic asset.

\section{Agile as Moderator}

Customers have requested more prominent actions from numerous brands for a long time. In any case, that demand has become distinctively louder as customers found their voices through the Internet. This will force organizations to work more closely with them. The customers eventually give impacts on the brands they interface with (Yan, 2011). Betts and Tadisina (2009) found that, agility positively moderates the effect of collaboration on supply chain performance. This finding 
INTERNATIONAL JOURNAL OF ACADEMIC RESEARCH IN BUSINESS AND SOCIAL SCIENCES Vol. 9, No. 1, Jan, 2019, E-ISSN: 2222-6990 @ 2019 HRMARS

encourages practitioners to cultivate a more agile supply chain by considering how agility influences the supply chain and further develop their supply chain accordingly. In the same vein, Gligor, Esmark and Holcomb (2015) also proved that agility moderates the effect of collaboration on supply chain performance. This correspond to agility as an outwardly focused capability, while flexibility is an inwardly focused competency. Notably, Betts and Tadisina (2009) further mentioned that collaboration can be improved and generates a positive effect on supply chain performance when an agile supply chain is present as exhibit in Figure 2.

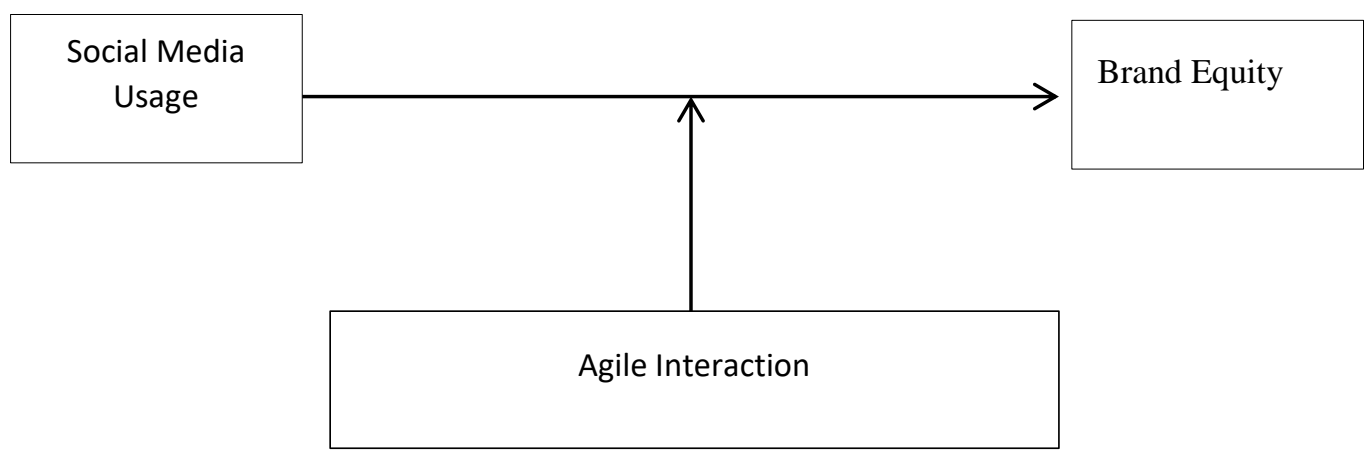

\section{Conclusion}

Figure 2: Hypothesized path model (Author, 2018)

This paper solely focused in providing a conceptual analysis of agile interaction. Based on the discussion above, an agile interaction appears to be important in marketing strategy particularly in making social media usage more effective. The review of the literature shows that it is an essential yet underexplored construct. The empirical works of its effect can explicitly operationalize as a moderating variable especially in marketing literature and specifically in branding strategy. The contribution of this study is to present a new hypothesis to explain social media usage and brand equity interaction. A study supported on quantitative analysis to validate the proposed model is recommended.

\section{References}

Baird, A., \& Riggins, F. J. (2012). Planning and Sprinting: Use of a Hybrid Project Management Methodology within a CIS Capstone Course. Journal of Information Systems Education, 23(3), 243-257. https://doi.org/10.1002/spip

Betts, T., \& Tadisina, S. K. (2009). Supply Chain Agility, Collaboration, and Performance: How do They Relate? In POMS 20th Annual Conference (pp. 1-22).

Bruce, M., Daly, L., \& Towers, N. (2004). Lean or Agile: A Solution for Supply Chain Management in the Textiles and Clothing Industry? International Journal of Operations \& Production Management, 24(2), 151-170. https://doi.org/10.1108/01443570410514867

Grönroos, C. (1994). From Marketing Mix to Relationship Marketing: Towards a Paradigm Shift in Marketing. Management Decision, 32(2), 4-20.https://doi.org/10.1108/00251749410054774

Christopher, M., Lowson, R., \& Peck, H. (2004). Creating Agile Supply Chains in the Fashion Industry. International Journal of Retail \& Distribution Management, 32(8), 367-376. 
INTERNATIONAL JOURNAL OF ACADEMIC RESEARCH IN BUSINESS AND SOCIAL SCIENCES

Vol. 9, No. 1, Jan, 2019, E-ISSN: 2222-6990 @ 2019 HRMARS

https://doi.org/10.1108/09590550410546188

Conboy, K., \& Fitzgerald, B. (2004). Toward a Conceptual Framework of Agile Methods : A Study of Agility in Different Disciplines. In WISER'04 (pp. 37-44).

DeFauw, R. (2012). Can Marketing Go Agile? Proceedings - 2012 Agile Conference, Agile 2012. https://doi.org/10.1109/Agile.2012.15

Gligor, D. M., Esmark, C. L., \& Holcomb, M. C. (2015). Performance outcomes of supply chain agility: When should you be agile? Journal of Operations Management, 33-34, 71-82. https://doi.org/10.1016/j.jom.2014.10.008

Hanssen, G. K., \& Fægri, T. E. (2006). Agile Customer Engagement: A Longitudinal Qualitative Case Study. In ISESE'06 - Proceedings of the 5th ACM-IEEE International Symposium on Empirical Software Engineering. https://doi.org/10.1145/1159733.1159759

Hellberg, M. (2015). Visual Brand Communication on Instagram : A study on consumer engagement.

Hu, Z. G., Yuan, Q., \& Zhang, X. (2009). Research on agile project management with scrum method. Proceedings - 2009 IITA International Conference on Services Science, Management and Engineering, SSME 2009, 3, 26-29. https://doi.org/10.1109/SSME.2009.136

Hunt, J. (2006). Agile Methods and the Agile Manifesto. In Agile Software Construction (pp. 9-30). https://doi.org/10.1007/1-84628-262-4_2

Hutter, K., Hautz, J., Dennhardt, S., \& Füller, J. (2013). The Impact of User Interactions in Social Media on Brand Awareness and Purchase Intention: The Case of MINI on Facebook. Journal of Product and Brand Management, 22(5), 342-351. https://doi.org/10.1108/JPBM-05-2013-0299

Johansen, M. (2012). Customer Engagement on Facebook : A Social Brand Experience?

Kamat, V. (2012). Agile Manifesto in Higher Education. In Proceedings - 2012 IEEE 4th International Conference on Technology for Education, T4E 2012 (pp. 231-232).

https://doi.org/10.1109/T4E.2012.49

Kim, K. H., Ko, E., Xu, B., \& Han, Y. (2012). Increasing Customer Equity of Luxury Fashion Brands through Nurturing Consumer Attitude. Journal of Business Research, 65(10), 1495-1499. https://doi.org/10.1016/j.jbusres.2011.10.016

Laroche, M., Habibi, M. R., \& Richard, M. O. (2013). To be or not to be in Social Media: HowBbrand Loyalty is Affected by Social media? International Journal of Information Management, 33(1), 76-82. https://doi.org/10.1016/j.ijinfomgt.2012.07.003

Mansor, Z., Yahya, S., Habibah, N., \& Arshad, H. (2012). Review on Traditional and Agile Cost Estimation Success Factor in Software Development Project. International Journal on New Computer Architectures and Their Applications (IJNCAA).

Mills, D., Sherrell, L., Boydstun, J., \& Guoqing Wei. (2006). Experiences using Agile Software Development for a Marketing Simulation. In Proceedings of the IEEE SoutheastCon 2006 (pp. 285-290). https://doi.org/10.1109/second.2006.1629365

Pan, J., Vorvoreanu, M., \& Zhou, Z. (2014). Social Media Adoption in Disaster Restoration Industry. Construction Innovation, 14(3), 346-369. https://doi.org/10.1108/Cl-03-2013-0014

Poolton, J., Ismail, H. S., Reid, I. R., \& Arokiam, I. C. (2006). Agile Marketing for the ManufacturingBased SME. Marketing Intelligence \& Planning, 24(7), 681-693. https://doi.org/10.1108/02634500610711851

Prange, C. (2016). Engaging with Complex Environments: Why Agility Involves more than Running 
INTERNATIONAL JOURNAL OF ACADEMIC RESEARCH IN BUSINESS AND SOCIAL SCIENCES

Vol. 9, No. 1, Jan, 2019, E-ISSN: 2222-6990 @ 2019 HRMARS

Hard. International Journal of Complexity in Leadership and Management, 3(3), 182-197. https://doi.org/10.1504/IJCLM.2016.10001219

Qumer, A., \& Henderson-Sellers, B. (2008). A Framework to Support the Evaluation, Adoption and Improvement of Agile Methods in Practice. Journal of Systems and Software, 81(11), 1899-1919. https://doi.org/10.1016/j.jss.2007.12.806

Rader, C. S., Subhan, Z., Lanier, C. D., Brooksbank, R., Yankah, S., \& Spears, K. (2014). CyberRx Emerging Social Media Marketing Strategy for Pharmaceuticals. International Journal of Pharmaceutical and Healthcare Marketing, 8(2), 193-225. https://doi.org/10.1108/IJPHM-052013-0027

Rascals, S. (2011). Agile : Marketing 's New Method. In Agile Marketing (pp. 1-44).

Royle, J., \& Laing, A. (2014). The digital marketing skills gap: Developing a Digital Marketer Model for the communication industries. International Journal of Information Management, 34(2), 65-73. https://doi.org/10.1016/j.ijinfomgt.2013.11.008

Sashi, C. M. (2012). Customer Engagement, Buyer-Seller Relationships, and Social Media. Management Decision, 50(2), 253-272. https://doi.org/10.1108/00251741211203551

Senn, C., Thoma, A., \& Yip, G. S. (2013). Customer-Centric Leadership: How to Manage Startegic Customers as Asses in B2B Markets. California Management Review, 55(3), 27-59.

Urban, G. L. (2005). Customer Advocacy: A New Era in Marketing ? Growth of Customer Power. Journal of Public Policy \& Marketing, 24(1), 155-159.

Von Rosing, M., Von Scheel, J., \& Gill, A. Q. (2014). Applying Agile Principles to BPM. The Complete Business Process Handbook: Body of Knowledge from Process Modeling to BPM (Vol. 1). Elsevier Inc. https://doi.org/10.1016/B978-0-12-799959-3.00027-6

Wilkie, W. L., \& Moore, E. S. (2003). Scholarly Research in Marketing : Exploring the " 4 Eras" of Thought Development. 116 Journal of Public Policy \& Marketing, 22(2), 116-146.

Wilson, K., \& Doz, Y. L. (2014). Agile Innovation: A Footprint Balancing Distance and Immersion. California Management Review, 53(2), 6-26.

Yam, R. C., Lo, W., \& Tang, P. Y. (2001). e-Agile Enterprising: The Manufacturing and Marketing Strategies to Enhance Global Competitiveness for Hong kong Manufacturing Industry. Management of Engineering and Technology, 2001. PICMET '01. Portland International Conference On, 33. https://doi.org/10.1109/PICMET.2001.951726

Yan, J. (2011). Social Media in Branding: Fulfilling a Need. Journal of Brand Management, 18(9), 688696. https://doi.org/10.1057/bm.2011.19

Zain, M., Rose, R. C., Abdullah, I., \& Masrom, M. (2004). The Relationship between Information Technology Acceptance and Organizational Agility in Malaysia. Information and Management, 42(6), 829-839. https://doi.org/10.1016/j.im.2004.09.001 